\title{
Vegetation Database of Deciduous Forests on Acidic Soils in NW Europe
}

\author{
Thilo Heinken
}

\begin{abstract}
The database of mixed oak and beech forests (Quercion roboris, Luzulo-Fagion) in NW Europe (DE, B, NL, PL) comprises 4,430 relevés, both from the lowlands and the adjacent hilly regions up to approximately $800 \mathrm{~m}$ a.s.l. It was created in the early $1990 \mathrm{~s}$ in order to re-evaluate the syntaxonomy of deciduous forests of acidic soils in the lowlands of NW and Central Europe based on \pm all available vegetation data. Only original relevés (Braun-Blanquet method) from 75 sources, published in local ecological journals or monographs, or unpublished material from diploma theses, are included. Plot sizes, complete structural data and exact geographic localisation are mostly not included in the electronic repository, but may be gained from the original publications in many cases. Beyond phytosociological classification and analysis of large-scale geographic patterns within plant communities, parts of the database have been intensively used to evaluate site characteristics of plant communities and the influence of historical land use patterns on present-day vegetation. Hosted by the department of biodiversity research and botany of the University of Potsdam, the data are available for collaborative research. This report describes the available content in the Vegetation Database of Deciduous Forests on Acidic Soils in NW Europe (GIVD ID EU-00-008).
\end{abstract}

Keywords: ecoinformatics; forest site classification.

GIVD Database ID: EU-00-008

Last update: 2012-05-03

\section{Vegetation Database of Deciduous Forests on Acidic Soils in NW Europe}

Scope: A database of mixed oak and beech forests (Quercion roboris, Luzulo-Fagion) in NW Europe (mainly DE, B, NL). Only original relevés (Braun-Blanquet method; published in local ecological journals or monographs, or unpublished) are included.

Status: finished

Period: 1936-2007

Database manager(s): Thilo Heinken (heinken@uni-potsdam.de)

Owner: Thilo Heinken (private)

Web address: [NA]

Availability: free upon request

Database format(s): TABWIN

Export format(s): [NA]

Publication: [NA]

Plot type(s): normal plots

Non-overlapping plots: 4,437

Total plot observations: 4,437

Plot-size range: $100-900 \mathrm{~m}^{2}$

Countries: BE: $29.0 \%$; DE: $68.0 \%$; NL: $2.0 \%$; PL: $1.0 \%$

$\begin{array}{ll}\text { Estimate of existing plots: }[\mathrm{NA}] & \text { Completeness: }[\mathrm{NA}] \\ \text { Number of sources: } 75 & \text { Valid taxa: }[\mathrm{NA}]\end{array}$

Forest: [NA] - Non-forest: [NA]

Guilds: all vascular plants: $100 \%$; bryophytes (terricolous or aquatic): $99 \%$; lichens (terricolous or aquatic): $99 \%$

Environmental data: altitude: $40 \%$; slope aspect: $12 \%$; slope inclination: $12 \%$; surface cover other than plants (open soil, litter, bare rock etc.): $8 \%$; soil pH: $7 \%$; other soil attributes: $15 \%$

Performance measure(s): cover: $100 \%$

Geographic localisation: point coordinates less precise than GPS, up to $1 \mathrm{~km}: 6 \%$; small grid (not coarser than $10 \mathrm{~km}$ ): $44 \%$; political units or only on a coarser scale (>10 km): $100 \%$

Sampling periods: 1930-1939: 1.0\%; 1940-1949: 1.0\%; 1950-1959: 8.0\%; 1960-1969: 4.0\%; 1970-1979: 48.0\%; 1980-1989: 19.0\%; 1990-1999: 18.0\%; 2000-2009: $2.0 \%$ Information as of 2012-07-12; further details and future updates available from http://www.givd.info/ID/EU-00-008

Thilo Heinken (heinken@uni-potsdam.de)

Biodiversity Research / Botany, University of Potsdam, Maulbeerallee 1, 14471 Potsdam, GERMANY 